\title{
GROWTH RESPONSE OF EDAMAME SOYBEAN INTERCROPPED WITH SWEET CORN AT DIFFERENT PLANTING DATES
}

\author{
Respons Pertumbuhan Kedelai Edamame Tumpangsari dengan Jagung Manis \\ dengan Waktu Tanam yang Berbeda \\ Hidayat Saputra $^{1^{*}}$ and Zainal Mutaqin ${ }^{1}$ \\ Department of Agronomy and Horticulture, College of Agriculture, University of Lampung \\ ${ }^{1}$ Food Crop Production Program, Lampung State Polytechnic, \\ Soekarno Hatta 10 Street, Rajabasa Bandar Lampung 35114, Indonesia \\ "E-mail correspondence: hidayat88saputra@gmail.com
}

\begin{abstract}
ABSTRAK
Tumpangsari merupakan salah satu sistem budidaya yang cocok untuk meningkatkan produktivitas lahan, terutama yang memiliki tingkat kesuburan rendah. Masalah utama dengan pola tanam tumpangsari adalah persaingan antar tanaman. Waktu tanam yang tepat dapat meminimalkan efek negatif persaingan antar tanaman sehingga dapat mengoptimalkan pertumbuhan dan produksi tanaman. Tujuan penelitian ini adalah untuk mengetahui waktu tanam terbaik pada pola tumpangsari jagung manis dan kedelai edamame. Perlakuan terdiri dari 4 waktu tanam yaitu kedelai edamame ditanam monokultur (T0), kedelai edamame ditanam bersamaan dengan jagung manis (T1), kedelai edamame ditanam 7 hari sebelum jagung manis (T2), dan kedelai edamame ditanam 14 hari sebelum jagung manis (T3). Hasil penelitian menunjukkan bahwa perbedaan waktu tanam tidak menyebabkan penekanan pertumbuhan kedelai edamame yang ditumpangsarikan dengan jagung manis, sehingga kita bisa menerapkan waktu tanam yang sama antara kedelai edamame dan jagung manis dengan pola tumpang sari.
\end{abstract}

Kata kunci: Edamame, kompetisi, optimasi, pertumbuhan, tumpangsari, waktu tanam

\begin{abstract}
Multiple cropping system is one of the cultivation systems that is suitable for increasing land productivity, especially that with low fertility levels. The main problem with the intercropping cropping is competition between plants. The correct date of planting can minimize the negative effects of competition between plants so that it can optimize plant growth and production. The purpose of this study was to determine the best planting date in the intercropping pattern of sweet corn and edamame soybeans. The treatments consisted of 4 types in planting date: edamame soybeans monoculture (TO), edamame soybeans were planted simultaneously with sweet corn (T1), edamame soybeans were planted 7 days before sweet corn (T2), and edamame soybeans were planted 14 days before sweet corn (T3). The results showed that the difference in planting date did not lead to suppress of the growth of edamame soybeans at different planting dates with sweet corn in the intercropping system compared to monoculture system. So that we can apply the same planting date between edamame soybeans and sweet corn in intercropping system.
\end{abstract}

Keywords: Edamame, growth, intercropping, optimize, planting date 


\section{INTRODUCTION}

Edamame soybeans and sweet corn are agricultural commodities that are very popular with the community because they contain a lot of nutrients and have economic value (Aldillah, 2015). Agricultural intensification and diversification efforts can be made through the use of multiple cropping systems or intercropping patterns. The intercropping pattern is very suitable for increasing productivity on marginal agricultural lands or with relatively low fertility levels (Permanasari and Kastono, 2012; Midega et al., 2014). The cropping pattern of sweet corn intercropping with edamame soybeans has several advantages such as increased land productivity (Lithourgidis et al., 2011), land use efficiency (Wu and $\mathrm{Wu}, 2014)$, increased soil fertility, especially nitrogen (Zhang et $a l ., 2015)$, reduce the risk of crop failure due to pest attacks, produce more diverse crop products (Aisyah and Herlina, 2018; Zaeem et al., 2019), and increase the yield and land equal ratio (Edy et al, 2011).

The main problem of the intercropping pattern is the existence of competition between plants for taking nutrients, water, light absorption, and growing space. To reduce the competition between plants, it can be done by setting the planting date between sweet corn and edamame soybeans. The delay in planting one type of plant in the intercropping system will provide an opportunity so that when the plant needs maximum growth it does not coincide with other plants. This will help efforts to achieve the yield potential of the two types of intercropped plants. Based on the background, the purpose of this study was to determine the best planting date in the intercropping pattern of sweet corn and edamame soybeans.

\section{RESEARCH METHODS}

The research was conducted at the Lampung State Polytechnic Land and Plant
Laboratory, from July to November 2020. The materials used in this study included: Secada sweet corn seeds, Ryoko variety edamame soybean seeds, fertilizer Urea, SP$36, \mathrm{KCl}$, organic fertilizers (1 ton / ha), insecticides, fungicides, and herbicides. The tools used in this study were: hoe, tugal, knapsack sprayer, meter, analytical scale, and SPAD-502 plus chlorophyll meter.

The treatments consisted of three differences in planting dates: edamame soybeans were planted simultaneously with sweet corn (T1), edamame soybeans were planted 7 days before sweet corn (T2), and edamame soybeans were planted 14 days before sweet corn (T3). And as a comparison, it was edamame soybean monoculture treatment (T0). The treatments were arranged in a perfectly randomized block design (RKTS), with blocking based on direction of East-West.

The treatment was replicated 3 (three) dates so that there were 12 experimental plot units. Each experimental unit was a 4 x $3 \mathrm{~m}$ plot. From each experimental plot, 5 samples of edamame soybean were taken in different cropping lines. The similarity of the variance between treatments was tested by using the Bartlett test, the addition of the model was tested by the Tukey test. If the assumptions were met, the data was analyzed for variance. Hypothesis testing with Duncan's Multiple Range Test (DMRT). Data analysis was performed using Microsoft Excel and SAS 9.1 software.

Soil cultivation was done two weeks before planting. Planting was carried out two weeks after tillage. Prior to planting weeds were controlled by chemical and mechanical method. Each hole is planted with one seed and given an insecticide. The planting distance of sweet corn was $80 \mathrm{~cm}$ x $20 \mathrm{~cm}$ and edamame soybean was $40 \mathrm{~cm} \times 15 \mathrm{~cm}$. With one row of edamame soybeans between rows of sweet corn. The planting of sweet corn was in accordance with the treatment of differences in planting date with edamame, the difference between 7 days and 14 days after planting edamame soybeans. 
The fertilizer rates were as follows: organic fertilizer 1 ton ha ${ }^{-1}$, dolomite 1 ton ha ${ }^{-1}$, Urea $350 \mathrm{~kg} \mathrm{ha}^{-1}, 250 \mathrm{~kg} \mathrm{ha}^{-1} \mathrm{SP}-36$, and $\mathrm{KCl} 350$ $\mathrm{kg} \mathrm{ha}^{-1} . \mathrm{KCl}$ and urea fertilizers were applied by means of a hole in the side of the plant. The application of dolomite, SP-36, and organic fertilizers was carried out 1 week before planting by mixing SP-36 and organic fertilizers evenly on the soil with a hoe. Urea and $\mathrm{KCl}$ fertilizers were applied twice, at 1 and 4 weeks after planting.

The variables observed included plant height, number of leaves, number of branches, number of flowers, greenness of leaves, leaf temperature, and number of root nodules of edamame soybean plants

\section{RESULT AND DISCUSSION}

The results showed that there was no significant effect due to the treatment of differences in planting date between edamame soybean and sweet corn on the observed variables (Table 1).

The treatment of differences in planting date between edamame soybean and sweet corn did not significantly affect the height of edamame soybeans at 2 and 4 weeks of plant age (Table 2). Generally, the edamame soybean planted intercropping with sweet corn has a higher plant height than the edamame soybean grown in monoculture except for the difference in planting date of 7 days. This is thought to be due to the edamame soybean intercropped with competing with sweet corn plants in getting sunlight

Table 1. Recapitulation of Variance Analysis

\begin{tabular}{lc}
\hline \multicolumn{1}{c}{ Variable } & Significance \\
\hline Plant height 2 WAP & $\mathrm{ns}$ \\
Plant height 4 WAP & $\mathrm{ns}$ \\
Number of leaves 2 WAP & $\mathrm{ns}$ \\
Number of leaves 4 WAP & $\mathrm{ns}$ \\
Number of branches & $\mathrm{ns}$ \\
Number of flowers & $\mathrm{ns}$ \\
number of nodules & $\mathrm{ns}$ \\
Leaf greenness & $\mathrm{ns}$ \\
Leaf temperature & $\mathrm{ns}$ \\
\hline
\end{tabular}

$\mathrm{WAP}=$ Weeks after planting

ns $=$ Not significant at the $\alpha 5 \%$

Table 2. Effect of differences in planting date on the height of edamame soybean plants intercropped with sweet corn at 2 and 4 weeks

\begin{tabular}{lcc}
\hline \multirow{2}{*}{ Planting date } & \multicolumn{2}{c}{ Plant height $(\mathrm{cm})$ at age of } \\
\cline { 2 - 3 } & 2 weeks & 4 weeks \\
\hline Monocultur & 15.2 & 39.2 \\
Same planting date & 15.5 & 40.6 \\
7 days before sweet corn & 15.0 & 38.3 \\
14 days before sweet corn & 16.1 & 41.2 \\
\hline
\end{tabular}

The difference in planting date between edamame soybean and sweet corn did not significantly affect the number of edamame soybean leaves and number of branches (Table 3 and 4). The number of edamame soybean leaves planted intercropping with sweet corn generally has a higher number of leaves than the edamame soybean grown in monoculture. This also happened to the variable number of edamame soybean branches (Table 4). 
Observations of the level of greenness of the leaves and leaf temperature were carried out when the edamame soybeans were 6 weeks. Observations were carried out at 09.00 am and the 1-3 edamame soybean leaves. The results showed that the difference in planting dates between edamame soybean and sweet corn in the intercropping system had no significant effect on the variables of leaf greenness and leaf temperature of edamame soybean plants (Table 5). Shade from sweet corn plants at the same date of planting caused the temperature of edamame soybean leaves to be lower when compared to the monoculture system and those planted earlier than sweet corn (Table 5).

The difference in planting dates also had no significant effect on the variables of the number of root nodules and the number of edamame soybean flowers (Table 6). However, edmame soybeans were planted at the same date as sweet corn tends to have a lower number of root nodules and flowers than edamame soybeans planted earlier than sweet corn. In Table 6, it can also be seen that the edamame soybean intercropped with sweet corn has a lower number of root nodules and flowers than the monoculture system.

The difference in planting date between edamame and sweet corn in the intercropping system has not shown a significant effect on the morphological variables of edamame soybeans, namely plant height, number of leaves, number of branches, and number of flowers as well as on variables greenness of leaves and leaf temperature. The spacing used in this intercropping system are $80 \times 20 \mathrm{~cm}$ for sweet corn and $40 \times 15 \mathrm{~cm}$ for edamame soybeans. Edamame soybean spacing from sweet corn is $40 \mathrm{~cm}$. Position the edamame soybeans between the rows of sweet corn

Table 3. Effect of difference planting dates on the number of leaves of edamame soybean intercropped with sweet corn at 2 and 4 weeks age

\begin{tabular}{lcc}
\hline \multirow{2}{*}{ Planting date } & \multicolumn{2}{c}{ Number of leaves (trifoliate) at age of } \\
\cline { 2 - 3 } & 2 weeks & 4 weeks \\
\hline Monocultur & 2.3 & 9.6 \\
Same planting date & 2.5 & 9.8 \\
7 days before sweet corn & 2.4 & 9.8 \\
14 days before sweet corn & 2.6 & 10.3 \\
\hline
\end{tabular}

Table 4. Effect of different planting dates on the number of edamame soybean branches in the multiple cropping system with sweet corn at 6 weeks age

\begin{tabular}{ll}
\hline Planting date & Number of branches \\
\hline Monocultur & 3.7 \\
Same planting date & 4.2 \\
7 days before sweet corn & 4.4 \\
14 days before sweet corn & 4.5 \\
\hline
\end{tabular}


Table 5. Effect of different planting dates on the leaf greenness and leaf temperature of edamame soybean intercropped with sweet corn at 5 weeks age

\begin{tabular}{lcc}
\hline Planting date & Leaf greenness & Leaf temperature $\left({ }^{0} \mathrm{C}\right)$ \\
\hline Monocultur & 25.4 & 32.6 \\
Same planting date & 24.8 & 31.2 \\
7 days before sweet corn & 26.6 & 32.1 \\
14 days before sweet corn & 25.8 & 32.2 \\
\hline
\end{tabular}

Table 6. Effect of different planting dates on the number of nodules and flowers of edamame soybean intercropped with sweet corn

\begin{tabular}{lcc}
\hline Planting date & Number of nodules & Number of flowers \\
\hline Monocultur & 13.8 & 16.0 \\
Same planting date & 9.8 & 13.0 \\
7 days before sweet corn & 10.8 & 14.0 \\
14 days before sweet corn & 11.4 & 14.0 \\
\hline
\end{tabular}

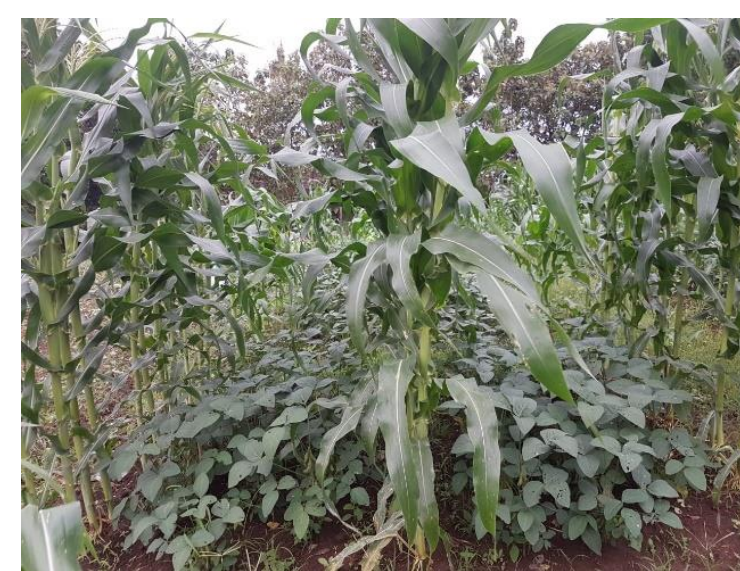

Figure 1. Crop growth with same planting date, at 8 weeks of age

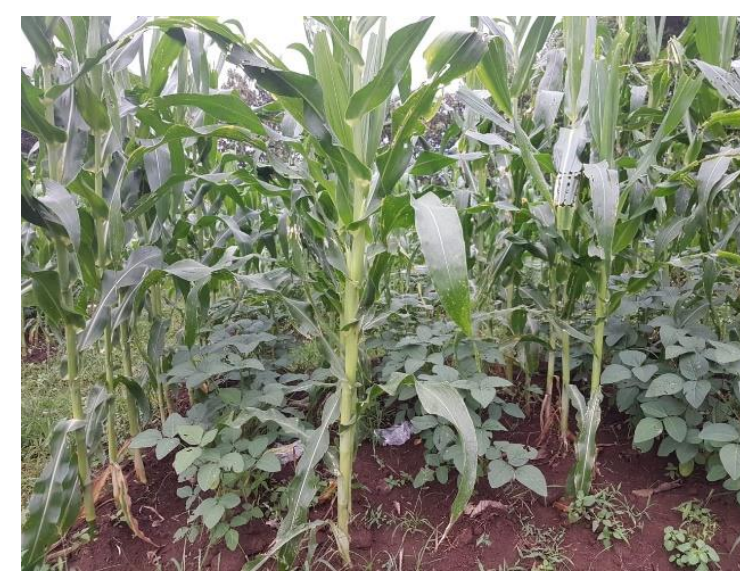

Figure 2. Crop growth with 7 days planting date sequential, at 8 weeks of age

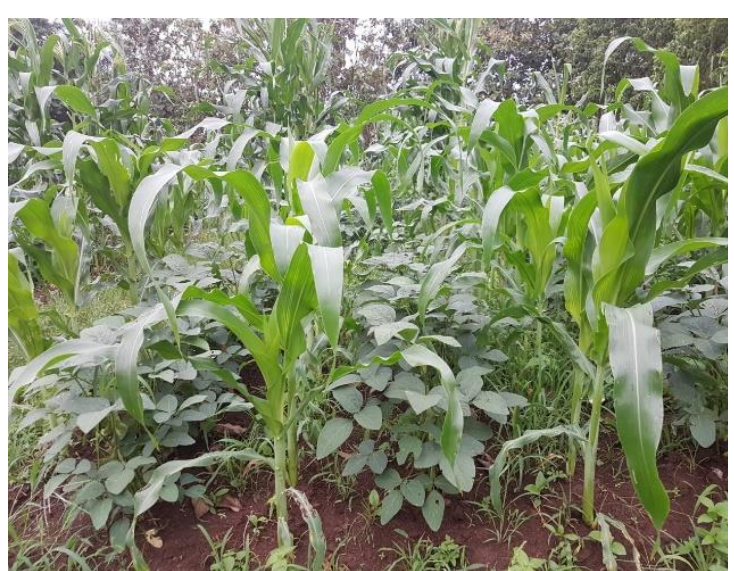

Figure 3. Crop growth with 14 days planting date sequential, at 8 weeks of age

The difference in planting date also had no significant effect on the variables of the number of root nodules and the number of edamame soybean flowers (Table 6). However, edmame soybeans were planted at the same date as sweet corn tends to have a lower number of root nodules and flowers than edamame soybeans planted earlier than sweet corn. In Table 6, it can also be seen that the edamame soybean intercropped with sweet corn has a lower number of root nodules and flowers than the monoculture system. 
The difference in planting date between edamame and sweet corn in the intercropping system has not shown a significant effect on the morphological variables of edamame soybeans, namely plant height, number of leaves, number of branches, and number of flowers as well as on variables greenness of leaves and leaf temperature. The spacing used in this intercropping system are $80 \times 20 \mathrm{~cm}$ for sweet corn and $40 \times 15 \mathrm{~cm}$ for edamame soybeans. Edamame soybean spacing from sweet corn is $40 \mathrm{~cm}$. Position the edamame soybeans is in between the rows of sweet corn (Figure 1-3).

The spacing used is still possible for the growth of edamame soybeans even though it is planted simultaneously with sweet corn. The same planting date with sweet corn has not caused growth suppression of edamame soybeans. Competition that occurs during the growth of the early vegetative phase is not very influential, but as the plant ages, the level of competition is higher (Ara, 2007; Pertiwi and Gosal, 2019). Furthermore, Syaifuddin (2010) states that when green bean plants are planted simultaneously with maize, the growth of mung bean plants does not show a depressed character

\section{CONCLUSION}

Based on the results, it can be concluded that the difference in planting dates did not lead to suppression of the growth of edamame soybeans at different planting dates with sweet corn in the intercropping system. So that we can apply the same planting date between edamame soybeans and sweet corn in an intercropping pattern with the spacing used in this study.

\section{ACKNOWLEDGEMENTS}

We would like to thank to UPPM Lampung State Polytechnic that has provided funds so that this research activity can be carried out.

\section{REFERENCES}

Aisyah, Y. and N. Herlina. 2018. The Effect of Spacing of Sweet Corn on the Intercropping of Three Varieties of Soybean. Jurnal Produksi Tanaman, 6(1): 66-75.

Aldillah, R. 2015. Projections of Indonesian soybean production and consumption. Jurnal Ekonomi Kuantitatif Terapan, (8)1: $9-23$.

Ara, W, M.K. Bashar, S Beghum and S.S. Kakon. 2007. Effect of Spacing and Stem Pruning and Growth and Yield of Tomato. Int. J. Sustain. Crop Prod. 2(3): 35-39.

Edy, Tohari, D. Indradewa, and D. Shiddieq. 2011. Response of maize intercropping mungbean to treatment of trench on dryland. Jurnal Agrotropika, 16(1): 3844.

Lihtourgidis A.S., C.A. Dorgas, C.A. Damalas, and D.N. Vlachostergios. 2011. Annual Intercrops: an alternative pathway for sustainable agriculture. Australian Journal of Crop Science, 5(4): 396-410.

Midega, C.A.O, D. Salifu, T.J. Bruce, J. Pittchar, J.A. Pickett dan Z.R. Khan. 2014. Cumulative effects and economic benefits of intercropping maize with food legumes on Striga hermonthica infestation. Field Crops Research. 155: 144-152.

Permanasari, I., dan D. Kastono. 2012. Intercropping Growth of Corn and Soybeans at Differences of Planting Time and Corn Trimming. Jurnal Agroteknologi. 3(1): 13-20.

Pertiwi and Gosal. 2019. Study of planting time on the intercropping pattern of corn and peanuts. Jurnal Perbal. 7 (1): 1-9.

Ratri, C., H., R., Soelistyono and N., Aini. 2015. Effect of planting time on Prei (Allium porrum L.) onions on the intercropping system on the growth and yield of sweet corn plants. Jurnal Produksi Tanaman, 3 (5): 406-412.

Syaifuddin, I. Mado, and Idris. 2010. The difference in planting time for green beans in corn planting. Jurnal Agrisistem, 6 (1) : $1-6$. 
Wu, K. X. and B. Z. Wu. 2014. Potential environmental benefits of intercropping annual with leguminous perennial crops in Chinese agriculture. Agriculture Ecosystems \& Environment, 188: 147149.

Zaeem M., M. Nadeem, T. H. Pham, W. Ashiq, W. Ali, S. S. M. Gilani, S. Elavarthi, V. Kavanagh, M. Cheema, L. Galagedara, and R., Thomas. 2019. The potential of corn-soybean intercropping to improve the soil health status and biomass production in cool climate boreal ecosystems. Nature Research, 9:13148. https://doi.org/10.1038/s41598-01949558-3.

Zhang, Y., J. Liu, J. Zhang, H. Liu, S. Liu, L. Zhai, H. Wang, Q. Lei, T. Ren and C. Yin. 2015. Row Ratios of Intercropping Maize and Soybean Can Affect Agronomic Efficiency of the System and Subsequent Wheat. PLOS ONE. DOI:10.1371/journal. pone. 0129245 . 